\title{
A new species of Melanophryniscus (Anura, Bufonidae) from Uruguay
}

\author{
Raúl Maneyro ${ }^{1,2,5}$, Daniel E. Naya ${ }^{1,3}$ \& Diego Baldo ${ }^{4}$
}

1. Sección Zoología Vertebrados, Facultad de Ciencias, Universidad de la República, Iguá 4225, 11400, Montevideo, Uruguay. (rmaneyro@fcien.edu.uy)

2. Laboratório de Herpetologia, Museu de Ciências e Tecnologia \& Faculdade de Biociências da Pontifícia Universidade Católica de Rio Grande do Sul. Av. Ipiranga 6681, 90619-900 Porto Alegre, RS, Brazil.

3. Center for Advanced Studies in Ecology \& Biodiversity, and Departamento de Ecología, Facultad de Ciencias Biológicas, Pontificia Universidad Católica de Chile, 6513677 Santiago, Chile. (dnaya@bio.puc.cl)

4. Laboratorio de Genética Evolutiva y Molecular, Departamento de Genética, Facultad de Ciencias Exactas, Químicas y Naturales, Universidad Nacional de Misiones, Félix de Azara 1552, 3300 Posadas, Misiones, Argentina. CONICET. (diegobaldo@ @ceqyn.unam.edu.ar) 5. Author for correspondence.

\begin{abstract}
A new species of bufonid toad of the genus Melanophryniscus from northern Uruguay is described. It is included in the $M$. moreirae group and its external morphology is similar to Melanophryniscus sanmartini. Melanophryniscus sp. nov. is distinguished by having a light brown dorsal coloration with six darker longitudinal glandular ridges on the dorsal surface of the body and the gular region uniformly black.
\end{abstract}

KEYWORDS. Anura, Melanophryniscus, Uruguay.

RESUMEN. Una nueva especie de Melanophryniscus (Anura, Bufonidae) del Uruguay. Se describe una nueva especie de anuro bufónido del género Melanophryniscus, procedente del norte de Uruguay. La nueva especie se incluye en el grupo M. moreirae y es similar, en cuanto a su morfología externa, con Melanophryniscus sanmartini. Melanophryniscus sp. nov. se distingue por presentar una coloración dorsal castaño clara con seis cordones glandulares longitudinales más oscuros en la superficie dorsal del cuerpo y la región gular de color negro uniforme.

PALABRAS CLAVE: Anura, Melanophryniscus, Uruguay.

The Neotropical genus Melanophryniscus Gallardo, 1961 is currently represented by 20 species distributed in southern and southeastern Brazil, southern Bolivia, Paraguay, Uruguay and central and northern Argentina (DI-BERNARDo et al., 2006). Although there is no accepted proposal of phylogenetic intrageneric relationships for Melanophryniscus, adult (GRAYBEAL \& CANNATElla, 1995) and tadpole characters (LARSON et al., 2003) suggest monophyly of the genus, and the available phylogenetic hypotheses propose Melanophryniscus as a basal member of the family Bufonidae (GRAYBEAL, 1997; HaAs, 2003; Darst \& CANNATElla, 2004; Faivovich et al., 2005). Melanophryniscus species are arranged in three (CRUZ \& CARAMASChI, 2003) or four phenetic groups (CÉsPedeZ \& MotTe, 2001). However, these groupings are not based on analytical methods of modern systematics and the only group for which a putative synapomorphy (presence of the frontal swelling) has been suggested is the $M$. tumifrons (Boulenger, 1805) group (BALDO \& BAsso, 2004; NAYA et al., 2004).

In Uruguay, there are six known species of Melanophryniscus: M. atroluteus (Miranda-Ribeiro, 1920 ) and M. montevidensis (Philippi, 1902) in the $M$. stelzneri (Weyenbergh, 1875) group (sensu CRUZ \& CARAMASCHI, 2003); M. sanmartini Klappenbach, 1968 in the M. moreirae (Miranda-Ribeiro, 1920) group (sensu Cruz \& Caramaschi, 2003); and $M$. devincenzii Klappenbach, 1968, M. orejasmirandai Prigioni \& Langone, 1986, and M. pachyrhynus (Miranda-Ribeiro, 1920 ) in the $M$. tumifrons group (sensu CRUZ \& CARAMASCHI, 2003).
The purpose of this work is to describe a new species of Melanophryniscus belonging to the $M$. moreirae group (sensu CRUZ \& CARAMASCHI, 2003), collected during a monitoring program in the modified woodlands of northern Uruguay.

\section{MATERIALS AND METHODS}

Type specimens are deposited at the Vertebrate Collection, Facultad de Ciencias, Universidad de la República, Montevideo, Uruguay (ZVCB). Measurements were taken with calipers to the nearest $0.01 \mathrm{~mm}$ under a dissecting microscope. The webbing formula is described using methods of SAVAGE \& Heyer (1967) and Myers \& DuEllman (1982). Drawings were made with the aid of a camera lucida attached to a Leyca MZ6 stereoscopic microscope.

Material examined. Melanophryniscus admirabilis $\mathrm{Di}$ Bernardo, Maneyro \& Grillo, 2006. BRAZIL, Rio Grande do Sul: Arvorezinha (Perau de Janeiro) (ZVCB 11531-33 Paratypes).

Melanophryniscus atroluteus. ARGENTINA, Misiones: Dep. Apóstoles (Barra Concepción) (MACN 1913-7, MLP DB 647, 651-92, 1423, 1428-30, 1438, 1442-3); Dep. Candelaria (Cerro Corá, San Juan stream) (MLP DB 161, 305-18, 1404, 1407-16, 1418, 1433, 1435, 1437, 1439-41, 1831); Dep. Capital (Villa Lanus, Campus UNaM, 27²6’03.8”S, 5553'11.3”W) (MLP DB 1425, 1475); Dep. Capital (Junction Prov. roads 105 and 204) (CHUNAM 596-600); Dep. Concepción (Concepción de la Sierra, Campo San Lucas) (MLP DB 176-8, 183-6); Dep. San Javier (Itacaruaré) (MCP 618); Corrientes: Dep. Ituzaingó (15 $\mathrm{km}$ west from San Carlos) (MACN 29565, 29567); Dep. Santo 
Tomé (Santo Tomé) (MFA-ZV.H 028). BRAZIL, Rio Grande do Sul: Garruchos (MCP 858-9, 861-5, 867-9); São Jose dos Ausentes (MCP 4607, 4609); Uruguaiana (Km 170 Road BR 472) (MNRJ 27349-50). URUGUAY, Artigas: Tomás Gomensoro (MLP DB 3990-2, 3994); Treinta y Tres: Bañado de las Oliveras (MLP DB 3993).

Melanophryniscus cambaraensis Braun \& Braun, 1979. BRAZIL, Rio Grande do Sul: Cambará do Sul (P.N. da Serra Geral, Fortaleza dos Aparados) (MCN 9797- Holotype, MCN 9755, 9757-60, 9762-88, 9790-92, 9794, 9799-9813, MNHN 04993 - Paratypes).

Melanophryniscus cupreuscapularis Céspedez \& Alvarez, 2000. ARGENTINA, Corrientes: Dep. Capital (Corrientes) (MFA-ZV.H 386-8); Dep. Capital (Perichón) (MLP DB 1053-5, 1759-62, 3425, 3537, MFA-ZV.H 286); Dep. Itatí (MACN 31311-54); Dep. San Luis del Palmar (Esteros de Maloyas) (MFAZV.H 321-4).

Melanophryniscus devincenzii. ARGENTINA, Misiones Dep. Candelaria (Prov. road 3, $3.5 \mathrm{Km}$ from Nat. road 12 , 27²9'26.5”S; 55³9'58.3"W) (MLP DB 753, 759, 802, 857, 876, 887, 889, 964, 1402-3); Dep. Candelaria (Puerto San Juan) (MLP DB 620-2, 1400-1); Dep. Capital (Parque Provincial Fachinal) (MACN 36856); Dep. San Pedro (MLP DB 1834). URUGUAY, Rivera: La Palma (Rubio Chico, close to Subida de Pena, Cuchilla Negra) (MNHN 1675 -Holotype).

Melanophryniscus dorsalis (Mertens, 1933). BRAZIL,

Santa Catarina: Imbituba (Praia de Itapirubá) (MNRJ 27337. 41); Santa Catarina (Laguna) (MCP 07660, MZUSP 71240-1); Rio Grande do Sul: Torres (MCP 233-44, 246-50, 252-265, 319-20, 6446-7, 6524-8, MNRJ 3022, 3037, 27342-4, 27346, MZUSP 102606-8)

Melanophryniscus fulvoguttatus (Mertens, 1937). PARAgUAY, (MNRJ 5855); Alto Paraguay: Puerto Primavera (FML 1868 - two specimens); Cororó (Río Ipané, $117 \mathrm{Km}$ from Concepción, on road towards Padre Juan Caballero) (MACN 21654); San Pedro (Carumbé) (FML 1447-11, FML 1815 - fou specimens); Concepción: Sapucaí (AL-MN 4735-6); Pavón (MNRJ 2666). BRASIL, Mato Grosso do Sul: Jardim (MNRJ 27347-8); Maracaju (MNRJ 4220-44, MZUSP 102330). ARGENTINA, Formosa (FML 02459).

Melanophryniscus klappenbachi Prigioni \& Langone, 2000. PARAGUAY, Alto Paraguay: Casado (Ea. Casilda) (MACN 8212). ARGENTINA, Chaco: Dep. Almirante Brown (Los Frentones) (MACN 33947-76); Dep. Bermejo (Río de Oro, Gral. Vedia) (MACN (CENAI) 08731); Dep. $1^{\circ}$ de Mayo (Río Tragadero) (MFA-ZV.H 413-4); Dep. San Fernando (Arroyo Palometa, Nat. Road 11) (MNHN 01496 - Holotype); Santa Fe: Dep. General Obligado (Florencia) (MLP 2268-72, MLP DB 1159); Dep. General Obligado (mouth of Sombrerito stream to Los Amores stream) (MZUC 2121:91, 2121:92, 2121:93); Santiago del Estero: Dep. Copo (Monte Quemado) (MACN 35421-9).

Melanophryniscus krauczuki Baldo \& Basso, 2004 ARGEnTINA, Misiones: Dep. Candelaria (1 Km W from Profundidad) (MLP DB 459-60, 693, 696-97, 699, 701-3, 705, 707-8, 1904-7); Dep. Candelaria (Ñ Pajú, Prov. road 3, $3.5 \mathrm{Km}$ from Nat. road 12, 27²9'26.5”S, 55³9'58.3”W) (MLP DB 744 - Holotype, MLP DB 719-20, 724-7, 730-2, 758, 739-40, 742$3,745-6,750-1,756-7,765-6,768-9,771-2,775,777,780-6$, 790, 807-8, 827-8, 830-1, 834, 864, 970-6, FML 10124-5, MACN 37141-2 - Paratypes).

Melanophryniscus macrogranulosus Braun, 1973. BRAZIL, Rio Grande do Sul: Don Pedro de Alcântara (Quarto Distrito de Porto Colônia, Porto Fagundes, Morro da Gruta, 2924'20"S; 3751'03"W) (MRCN 1694 - Holotype, MRCN 1693, 1695-99, 1701-2 - Paratypes).

Melanophryniscus montevidensis. URUGUAY,

Montevideo: Barra de Santa Lucía (CENAI (MACN) 3263 3281); Pajas Blancas (ZVCB 3814); Carrasco (ZVCB 430); Montevideo (FML 00039); Canelones: Bañados de Carrasco (ZVCB 328); Parque Roosevelt (ZVCB 820); Rocha: La Paloma (MACN 25188, 25190, ZVCB 1892); Cabo Polonio (ZVCB 1900 1905); La Coronilla (FML 03687).

Melanophryniscus moreirae. BRAZIL, Rio de Janeiro: Itatiaia (CENAI (MACN) 8732 -Paratype, MLP A. 1071, MLP A. 1804-5).
Melanophryniscus orejasmirandai. URUGUAY, Lavalleja: Cerro Cotto (11.5 km East from Solís de Mataojo) (ZVCB 8128); Maldonado: Cerro de Animas (MLP DB 3987-8, MNHN 5476 - Holotype, MZUSP 061112 - Paratype, ZVCB 7275). Melanophryniscus pachyrhynus. BRAZIL, Rio Grande do Sul: São Lourenço (MZUSP 000752 - Paralectotype, MZUSP 000756 - Lectotype). URUGUAY, Cerro Largo: Cuchilla del Mangrullo (ZVCB 11097-8).

Melanophryniscus rubriventris (Vellard, 1947).

ARGENTINA, Jujuy: Dep, Gral, San Martín (Parque Nacional Calilegua, Abra de Cañas) (MFA-ZV.H 268 - 2 specimens, MLP DB 453, 471-5, 650, 1462-5); Dto. San Antonio (Río Morado, springs of Perico river) (MLP DB 573, 1466, 1776-7).

Melanophryniscus sanmartini. URUGUAY, Rivera: 20 Km SE from Rivera (Ea. Trinidad , Compañía Forestal Uruguaya) (ZVCB 6127-8, 8981); Rocha establishment (Compañía Forestal Uruguaya) (ZVCB 9390, 6377, 8206), Vazquez establishment (Compañía Forestal Uruguaya) (ZVCB 6373-4, 8132, 8189-90, 8358). Lavalleja, Villa Serrana (close to Arroyo Aiguá dam) (MNHN 1676 - Holotype).

Melanophryniscus simplex Caramaschi \& Cruz, 2002. BRAZIL, Santa Catarina: Municipality of São Joaquim (Boca da Serra, close to Bom Jardim do Sul) (MZUSP 35599 - Holotype, MNRJ 25943-5, MZUSP 35596, 35600-4 - Paratypes).

Melanophryniscus spectabilis Caramaschi \& Cruz, 2002. BRAZIL, Santa Catarina: Nova Teutonia (MLP A. 1802-3, MNRJ 25936-42 - Paratypes, MZUSP 9424 - Holotype, 940920, 9440, 9447-59, 9470-73, 9475-84, 9486-92, 9494-5, 9498501, 9508-9 - Paratypes, MLP A. 1802-3).

Melanophryniscus stelzneri spegazzinii Gallardo, 1961. ARGENTINA, Salta: Dep. La Viña (La Viña) (MACN 4217 Holotype and two Paratypes).

Melanophryniscus stelzneri stelzneri. ARGENTINA,

Córdoba: Dep. Calamuchita (Altos Pampa, Río Reartes) (CENAI (MACN) 4125-6); Dep. Colón (Pozo Azul) (MLP DB 617, $1393-$ 9, 1763); Dep. Colón (San Jorge) (MACN 867-78); Dep. Dean Funes (Villa Albertina) (MLP DB 1764, MFA-ZV.H 307-9); Dep. Pocho (Las Chacras) (MACN 33150-1); Dep. Punilla (El Durazno) (CENAI (MACN) 4129, FML 02547 - five specimens); Dep. Punilla (Icho Cruz) (FML 03915); Dep. Punilla (Pampa de Achala) (CENAI (MACN) 3310-1, 10914, 10917, MACN 33831); Dep. Punilla (Tanti) ( CENAI (MACN) 111 - three specimens, 14378, MACN 7107-16, 13822, 28323-6, 4136 - 42 specimens, MLP 0112); Dep. San Alberto (Mina Clavero) (MACN 23336-41, 28285 - 16 specimens, MLP 0444); Dep. San Javier (Los Hornillos) (MACN 16417). San Luis: (CENAI (MACN) 4346, MACN 4705-6, 4823); Dep. Chacabuco (Concarán) (MACN 32244); Dep. Coronel Pringles (La Toma) (MACN 28568-80); Dep. Gral. Pedernera (El Morro, Ea. La Emboscada) (CENAI (MACN) 10223).

Melanophryniscus tumifrons. BRAZIL, Rio Grande do Sul: (BMNH 1947.2.1461 - Holotype).

The abbreviations (acronyms) for Institutions are as follows: British Museum Natural History, (BMNH), London, England; Centro Nacional de Investigaciones Iológicas (CENAI, now within MACN collection); Facultad de Ciencias, Universidad de La República (ZVCB), Montevideo, Uruguay; Fundación Miguel Lillo, Instituto de Herpetología (FML), Tucumán, Argentina; Museo Argentino de Ciencias Naturales Bernardino Rivadavia (MACN), Buenos Aires, Argentina; Museo de La Plata (MLP), Buenos Aires, Argentina; Museo de Zoología, Universidad Nacional de Córdoba (MZUC), Córdoba, Argentina; Museo Florentino Ameghino (MFAZV.H), Santa Fe, Argentina; Museo Nacional de Historia Natural (MNHN), Montevideo, Uruguay; Museu de Ciências e Tecnologia of the Pontifícia Universidade Católica do Rio Grande do Sul (MCP), Porto Alegre, Brasil; Museu de Ciências Naturais da Fundação Zoobotânica do Rio Grande do Sul (MCN), Porto Alegre, Brasil; Museu Nacional (MNRJ), Rio de Janeiro, Brazil; Museu de Zoologia da Universidade de São Paulo, São Paulo, Brazil (MZUSP); Universidad Nacional de Misiones (CHUNAM) Posadas, Argentina. 


\section{Melanophryniscus langonei sp. nov. Fig. 1}

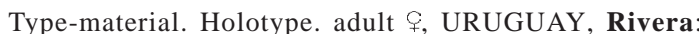
Establecimiento Trinidad $\left(30^{\circ} 59^{\prime} \mathrm{S}, 55^{\circ} 26^{\prime} \mathrm{W}\right.$, approximately $230 \mathrm{~m}$ elevation) 23.III.2001, R. Maneyro and D. E. Naya, cols. (ZVCB

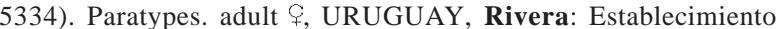
Vázquez ( $31^{\circ} 11^{\prime} \mathrm{S}, 55^{\circ} 21^{\prime} \mathrm{W}$, approximately $190 \mathrm{~m}$ elevation) 12.IV.2001, D. E. Naya, cols. (ZVCB 6375); adult $\$$, 07.VII.2001, D. E. Naya, cols. (ZVCB 8129); juvenile, approximately $230 \mathrm{~m}$ elevation, 14.IX.2001, D. E. Naya, cols. (ZVCB 8336); adult $q$, 12.I.2002, D. E. Naya, cols. (ZVCB 9389).

Diagnosis. Small size, without swelling on snout, two paravertebral glandular ridges along the body from the end of the snout to the urostile, two discontinuous glandular ridges on both sides of the body, extending from the upper eyelid and scapular region to posterior end of body respectively, dorsal color of head and body light brown with glandular ridges darker, upper surfaces of appendages and upper eyelid dark brown, gular and pectoral zone uniformly black, belly black with large, reticulated orange-red spots.

Melanophryniscus langonei is very similar to $M$. sanmartini. These two species can be distinguished as follows (characters of $M$. sanmartini in parentheses): dorsum with longitudinal glandular ridges (dorsum with rounded glandular warts scattered more abundantly in the head), dorsal color light brown with the glandular ridges darker (dorsal color dark brown with light brown spots), gular region black uniformly (gular region black with an ocher blotch just near tip).

The new species is distinguished from $M$. moreirae and from M. stelzneri group species (M. stelzneri, M. montevidensis, $M$. atroluteus, M. dorsalis, $M$. fulvoguttatus, $M$. rubriventris, $M$. cupreuscapularis, $M$. klappenbachi and M. krauczuki) by dorsal coloration patterns and distribution of glandular warts. Melanophryniscus langonei sp. nov. is easily distinguished from the members of the $M$. tumifrons group (M. tumifrons, M. pachyrhynus, M. devincenzii, $M$. macrogranulosus, M. cambaraensis, . orejasmirandai, $M$. simplex and $M$. spectabilis) by the smaller size and absence of swelling on snout.

Description of Holotype. Body stout; head slightly broader that long $(\mathrm{HL} / \mathrm{HW}=0.90)$ approximately one third of SVL; snout short, mucronated in dorsal view, slightly rounded in lateral profile; nostrils oval directed anterolaterally; eyes large, eye diameter smaller than interocular distance and larger than eye-nostril distance, pupil horizontally elliptical; snout swelling absent; tympanic membrane absent; parotid gland absent; maxillae and premaxillae edentate; tongue short, narrow and elongate, posterior margin entirely rounded, free for about two thirds of length posteriorly; skin of dorsum scattered with glandular warts; each wart tipped with one white keratinized spine; vertebral line smooth, without glandular warts; two paravertebral glandular ridges along the body from the snout to the end of the urostile; two discontinuous glandular ridges on both sides of the body, extended from the upper eyelid and scapular region respectively to posterior end of body; upper eyelid with numerous warts; surface of forearms, hands and feet scattered with coni; skin of venter finely granular; lengths of fingers: IV < II < I < III; fingers blunt, short and slightly webbed; subarticular tubercles conical and well developed, divided on fingers I and III; inner metacarpal tubercle oval; outer metacarpal tubercle rounded, equal in size at the inner; palmar supernumerary tubercles conical and scattered; lengths of toes: I $<$ II $<$ V $<$ III $<$ IV; toes webbed; webbing formula I 1-1 II $1^{1 / 2}-1$ III $2-1^{1 / 2}$ IV $1^{1 / 2}$ $2 \mathrm{~V}$; inner metatarsal tubercle oval; outer metatarsal tubercle rounded, one times smaller than inner; subarticular tubercles conical, divided on fingers I and IV; small supernumerary tubercles scattered in distribution.

Color in Life. Dorsal color of head and body light brown; longitudinal glandular ridges darker; vertebral line light brown; upper eyelid brown; loreal region light brown; upper surfaces of appendages and flanks brown; light brown stripe on upper arms; ventral head and pectoral zone uniformly black; belly black with mottled orange-red spots; an orange band on ventral surface of upper arms; posterior surfaces of thighs with a large orange-red spot; palmar surfaces of hands and fingers red; plantar surfaces of feet and toes $\mathrm{V}$ black, with red tubercles; ventral surface of toes I, II, III and IV red. In preservative (70\% ethanol) red areas described above are whitish.

Measurements of Holotype (in mm). Snout-vent length (SVL) 21.29, head length (HL) 7.17, head width (HW) 7.99, eye diameter (ED) 2.19, interorbital distance (IOD) 2.78, eye-nostril distance (END) 1.93, internarial distance (IND) 1.82, upper eyelid width (UEW) 2.00, upper eyelid length (UEL) 3.36, thigh length (TL) 8.03, shank length (SL) 7.24, foot length (FL) 7.99, tarsus length (TAL)

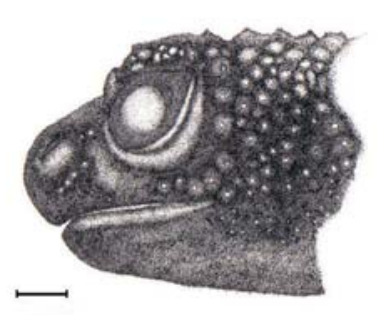

A

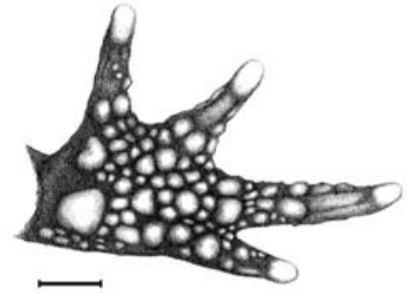

B

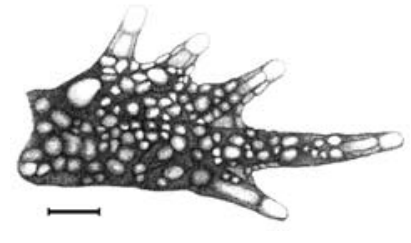

$\mathrm{C}$

Fig. 1. Morphological features of Melanophryniscus langonei sp. nov. (drawings based on the holotype, ZVCB 5334). (A, head in lateral view. B, left hand in ventral view. C, left foot in ventral view). Scale bar, $1 \mathrm{~mm}$. 


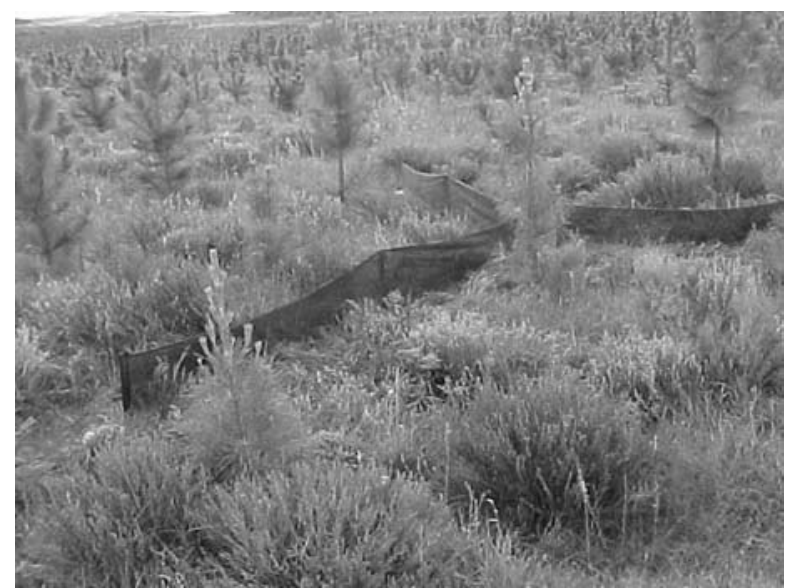

Fig. 2. Type locality of Melanophryniscus langonei sp. nov. In the photo one of the drift fences can be seen among the Pinus crops.

\subsection{5, upper arm length (UAL) 5.04, forearm length (FAL)} 5.2, hand length (HAL) 5.71.

Variation. The range of measurements (in millimeters) of adult paratypes are $(\mathrm{N}=3$, average given in parenthesis): SVL 20.49-21.52(21.01), HL 6.89-7.41 (7.15), HW 6.92-7.02 (6.97), ED 2.10-2.15 (2.13), IOD 2.47-2.61 (2.54), END 1.71-1.76(1.74), IND 1.48-1.70 (1.59), UEW 1.86-2.08 (1.97), UEL 3.09-3.20 (3.15), TL 7.53-8.27 (7.9), SL6.06-7.34(6.7), FL 6.68-7.73 (7.21), TAL 4.77-5.48(5.13), UAL 5.05-5.34 (5.20), FAL 4.79-4.92 (4.86), HAL 5.41-6.04 (5.73). There is know only one juvenile specimen $(12.9 \mathrm{~mm}$ in SVL), which has the same external characteristics of the adults.

Unknown.

Advertisement Call, Tadpoles and Karyotype.

Etymology. The specific name is in honor of Lic. José Langone, Uruguayan herpetologist, who has developed studies on South American amphibians, especially about the Melanoprhyniscus genus.

Distribution and Natural History. Melanophryniscus langonei is only known from two localities separated by about $15 \mathrm{Km}$ in the Departament of Rivera, northern Uruguay. This is a soft hilly area; with an open landscape and predominance of grasslands; surrounded by small streams; and currently modified by Eucaliptus sp. (Myrtaceae) and Pinus sp. (Pinaceae) plantations (Fig. 2). In these two places, specimens of $M$. sanmartini Klappenbach, 1968 were also collected (NAYA $\&$ MANEYRo, 2000). Although, specimens of M. langonei were found in all seasons of the year, their frequency of capture (about 1/1000 individuals) was the lowest of the 23 anuran species collected in the study area. Some circumstantial reproductive evidence, as the presence of mature ovules in May (ZVCB 6375) and the collection of a juvenile in September, could indicate that reproduction in M. langonei takes place during winter.

Acknowledgments. To Companía Forestal Uruguaya (COFUSA) for economic support to the research program. To
Dr. W. Ronald Heyer for critical review of the manuscript. R. M. has a doctoral fellowship from Coordenação de Aperfeiçoamento de Pessoal de Nível Superior (CAPES) at PUCRS. D. E. N. acknowledges financial support from PEDECIBA (Uruguay), CASEB (Fondecyt, Chile), and CONICYT (Chile). We are grateful to R. Stetson (CHUNAM), S. Kretzschmar, M. Cénepa, and E. Lavilla (FML), G. Carrizo (MACN), M. Di-Bernardo (MCP), M. Borges Martins (MCN), C. Virasoro and E. Fioramonti (MFA), J. Williams (MLP), J. Langone (MNHN), U. Caramaschi and C. A. G. Cruz (MNRJ), H. Zaher (MZUSP), for providing working space at their respective institutions. We thank M. Ledesma for producing the drawings.

\section{REFERENCES}

Baldo, D. \& Basso, N. G. 2004. A new species of Melanophryniscus Gallardo, 1961 (Anura: Bufonidae), with comments on the species of the genus reported for Misiones, northeastern Argentina. Journal of Herpetology 38:140-150.

Céspedez, J. A. \& Motte, M. 2001. Distribución de sapos del gênero Melanophryniscus (Gallardo, 1961) en Argentina y Paraguay (Anura: Bufonidae). Boletín de la Asociación Herpetológica Española 12:71-76.

Cruz, C. A. G. \& Caramaschi, U. 2003. Taxonomic status of Melanophryniscus stelzneri dorsalis (Mertens, 1933) and Melanophryniscus stelzneri fulvoguttatus (Mertens, 1937) (Amphibia, Anura, Bufonidae). Boletim do Museu Nacional, Nova Série, Zoologia, 500:1-11.

Darst, C. R. \& Cannatella, D. C. 2004. Novel relationships among hyloid frogs inferred from $12 \mathrm{~S}$ and $16 \mathrm{~S}$ mitochondrial DNA sequences. Molecular Phylogenetics and Evolution 31:462-475.

Di-Bernardo, M; Maneyro, R. \& Grillo, H. 2006. A new species of Melanophryniscus (Anura: Bufonidae) from Rio Grande do Sul, southern Brazil. Journal of Herpetology 40:261-266.

Faivovich, J.; Haddad, C. F. B.; Garcia, P. C. A.; Frost, D. R.; Campbell, J. A. \& Wheeler, W. C. 2005. Systematic review of the frog family Hylidae, with special reference to Hylinae: phylogenetic analysis and taxonomic revision. Bulletin of the American Museum of Natural History 24:1-240.

Graybeal, A. 1997. Phylogenetic relationships of bufonid frogs and tests of alternate macroevolutionary hypotheses characterizing their radiation. Zoological Journal of the Linnean Society 119:297-338.

Graybeal, A. \& Cannatella, D. C. 1995. A new taxon of Bufonidae from Peru, with descriptions of two new species and a review of phylogenetic status of supraspecific bufonids taxa. Herpetologica 51:105-131.

HaAs, A. 2003. Phylogeny of frogs as inferred from primarily larval characters (Amphibia: Anura). Cladistics 19:23-89.

Larson, P. M.; De SÁ, R. O. \& Arrieta, D. 2003. Chondrocranial, hyobranchial and internal oral morphology in larvae of the basal bufonid genus Melanophryniscus (Amphibia: Anura). Acta Zoologica 84:87-97.

Myers, G. W. \& Duellman, W. E. 1982. A new species of Hyla from Cerro Colorado, and other tree frog records and geographical notes from western Panama. American Museum Novitates 2752:1-32.

NAYA, D. \& MANEYRo, R. 2000. Melanophryniscus sanmartini Klappenbach, 1968 (Anura, Bufonidae). Cuadernos de Herpetología 15:89-90.

Naya, D.; Langone, J. A. \& De SÁ, R. O. 2004. Características histológicas de la tumefacción frontal de Melanophryniscus (Amphibia: Anura: Bufonidae). Revista Chilena de Historia Natural 77:593-598.

Savage, J. M. \& Heyer, W. R. 1967. Variation and distribution in the tree-frog genus Phyllomedusa in Costa Rica, Central America. Beiträge zur Neotropischen Fauna 5:111-131.

Recebido em março de 2006. Aceito em outubro de 2007. ISSN 0073-4721

Artigo disponível em: www.scielo.br/isz 